\title{
DUSZPASTERSTWO WOBEC BŁOGOSŁAWIEŃSTWA ZWIERZĄT
}

\author{
PASTORAL MINISTRY FOR THE BLESSING OF ANIMALS
}

\begin{abstract}
A b s t r a c t. Animals, while accompanying humans in ages, have always performed various functions: from escorting and taking care of them, through nourishment and supplying materials, to religious reasons. In christianity animals were and are a part of the Creation, for which human is thankful to the Creator. They also appear as saints' attributes, however they are no longer worshiped. Same as the whole world, both animate and inanimate, animals can be blessed to serve humans better on the path to eternal life. The interesting example of the blessing ritual of animals cited in the article is solemn indulgence of St. Roch from Montpellier in Mikstat. Animals are blessed there, but it is not the core of the ceremonial, which is mostly a celebration of the Word and administration of the sacraments, which serves admiration of God and is leading people to salvation. Nowadays, the needs and rights of animals are often raised on a par with humans, which is reflected in attempts to organize funerals, holy masses and other sacraments for animals. This undoubtedly raises serious challenges for theology and pastoral ministry.
\end{abstract}

Key words: animals; blessing; pastoral ministry; man; Creator; Saint Roch from Montpellier; Mikstat.

Celem duszpasterstwa ukształtowanego w duchu Soboru Watykańskiego II jest pomoc człowiekowi w procesie zbawienia, które dokonuje się poprzez dialog miłości między człowiekiem a osobami Bożymi. Kościół pomaga swoim wiernym przede wszystkim poprzez głoszenie słowa Bożego, celebrację liturgii oraz animację miłości braterskiej. Głównym podmiotem duszpasterstwa jest Bóg, następnie

Dr hab. JeRzy BRusito OFMConv - adiunkt w Instytucie Teologii Praktycznej Uniwersytetu Papieskiego Jana Pawła II; adres do korespondencji: pl. Wszystkich Świętych 5, 31-004 Kraków; e-mail: jerzy.brusilo@upjp2.edu.pl; ORCID: http://orcid.org/0000-0002-3962-1950

Dr. Hab. Jerzy BrusiŁo O.F.M.Conv. - Assistant Professor in Institute of Pastoral Theology, Faculty of Theology Pontifical University of John Paul II in Krakow; address for correspondence: pl. Wszystkich Świętych 5, 31-004 Kraków; e-mail: jerzy.brusilo@upjp2.edu.pl; ORCID: http://orcid. org/0000-0002-3962-1950 
Kościół jako wspólnota ludu Bożego oraz człowiek w licznych grupach i instytucjach ${ }^{1}$. Zatem zwierzęta, przyroda, środowisko naturalne nie są ani celem, ani podmiotem działania duszpasterskiego, ale mogą być przedmiotem duszpasterstwa, czego przejawem byłoby stosowane niekiedy błogosławieństwo zwierząt.

Zwierzęta oswojone, hodowlane i pociągowe przez długie wieki chrześcijaństwa wypełniały ustalone przez Stwórcę zadania i zajmowały swoje podporządkowane miejsce przy człowieku (pomijając to, czy były właściwie traktowane przez człowieka), ale o duszpasterstwie z uwzględnieniem zwierząt mowy nie było. Problem zaczął się wtedy, gdy zmienił się stosunek człowieka do zwierząt i stały się one albo ubóstwione i uduchowione (wymagające uświęcenia, zbawienia i łaski), albo uczłowieczone i równe ludziom (wymagające traktowania jak ludzie, także religijnie). W tej sytuacji - w duszpasterstwie, a ściślej w pobożności ludowej - występuje tzw. poświęcenie zwierząt, w takim rozumieniu tego obrzędu, że ich poświęcenie będzie sprzyjać zdrowiu zwierzęcia, poprawie jego wydajności, większych korzyści dla właściciela, hodowcy.

Czy takie „poświęcenie” (lepiej: „błogosławieństwo”) pogłębia wiarę opiekuna, właściciela zwierzęcia? Czy w ogóle posiadanie zwierząt przez ludzi wpływa na ich religijność? A może osoba wierząca, pragnąc przez błogosławieństwo „uświęcić zwierzę" lub starając się o błogosławieństwo dla zwierzęcia, sama przez to chce stać się świętsza? Czy nie wydaje się, że przy okazji tego działania nieświadomie zostaje przeniesiony na zwierzę obowiązek katolika, np. uczestniczenia we Mszy Świętej, modlitwy, praktyki miłości bliźniego, a po błogosławieństwie zwierzęcia jego właściciel mógłby zająć się więcej sprawami doczesnymi niż nadprzyrodzonymi? W drugim przypadku - wobec liberalnej, zmienionej antropologii i utylitarnego zrównania człowieka ze zwierzęciem - czy nie zaczęło się traktowanie zwierząt jakby byli ludźmi (humanizacja zwierząt), a w konsekwencji traktowanie ludzi jakby byli zwierzętami ${ }^{2}$ lub istotami bez praw i godności (np. dzieci nienarodzone lub „źle urodzone”)? Jak w duszpasterstwie można w ogóle praktykować „,poświęcenie” (błogosławieństwo) zwierząt? Powyższe pytania i dylematy są przedmiotem refleksji ujętej w tym opracowaniu.

\footnotetext{
${ }^{1}$ Por. Ryszard KAmiŃski i Wiesław PrzYGoda, „Duszpasterstwo”, w Leksykon teologii pastoral$n e j$, red. Ryszard Kamiński, Wiesław Przygoda i Marek Fiałkowski (Lublin: Towarzystwo Naukowe KUL, 2006), 202.

${ }^{2}$ Por. Jan Śledzianowski, Dehumanizacja człowieka i humanizacja zwierząt (Kielce: Jedność, 2014), 45-58.
} 


\section{ZWIERZĘTA W ŻYCIU I RELIGIJNOŚCI CZŁOWIEKA}

Przyroda w prehistorii ludzkiej, jak wskazują źródła etnograficzne, była silnie nasycona nadprzyrodzonością. Rośliny, zwierzęta, części przyrody nieożywionej (kamienie, góry, Słońce, Księżyc) i zjawiska fizyczne (burze, błyskawice) miały duszę, znaczenie magiczne i boskie. Religijne znaczenia przypisywane zwierzętom były powszechne w paleolicie, w społecznościach myśliwsko-zbierackich, gdy boski ideał wyrażał się w postaciach czy częściach zwierząt z potężną siłą mięśni, świetnym wzrokiem i słuchem, zdolnością poruszania się w powietrzu i na ziemi z wielką szybkością ${ }^{3}$. Zwierzęta były też składane jako ofiary, a jako źródło pożywienia człowieka były nierzadko traktowane jako dar od bogów.

Udomowienie zwierząt stało się ważnym czynnikiem wpływającym na rozwój człowieka w różnych kulturach i miejscach na świecie w okresie jego osiadłego trybu życia. Oswajano różne gatunki, najczęściej ssaki, w południowo-zachodniej i środkowo-południowej Azji (koza i owca) i na Bliskim Wschodzie (bydło) w okresie neolitu, od ok. 7000 lat przed Chrystusem ${ }^{4}$. Od początku udomowienia np. bydła, uważanego za gatunek idealny do wykorzystania przez człowieka (łagodne usposobienie, łatwe podporządkowanie człowiekowi, poza mięsem i skórą, wykorzystanie także mleka), towarzyszyła „,koewolucja relacji człowiek-zwierzę obejmująca nie tylko agrokulturę i potrzeby pokarmowe człowieka, ale szeroko pojętą kulturę ludzką, w tym przede wszystkim sferę symboliki i wierzeń"s.

Religia Izraela, a później chrześcijaństwo zmieniły nadprzyrodzone postrzeganie zwierząt, które chociaż towarzyszą i pomagają człowiekowi w historii zbawienia ${ }^{6}$, uosabiają cnoty i wzory postępowania ${ }^{7}$, pomagają w zrozumieniu prawd wiary i uczą posłuszeństwa Bogu, ale nie mają już sakralnego znaczenia. Oślica Balaama, klękająca przed aniołem Pana, nie wyraża aktu wiary sama od siebie, ale jest to przedstawiona obrazowo nauka dla jej pana - Balaama, jak być posłusznym Bogu oraz że Balaam niesprawiedliwie trzy razy pobił kijem swoją oślicę (por. Lb 22, 22-35).

\footnotetext{
${ }^{3}$ Por. Andrzej Szyjewski, Etnologia religii (Kraków: Zakład Wydawniczy Nomos, 2001), 118.

${ }^{4}$ Por. Alicja Lasota-Moskalewska, Zwierzęta udomowione $w$ dziejach ludzkości (Warszawa: Wydawnictwo Uniwersytetu Warszawskiego, 2005), 31.

${ }^{5}$ Por. Krzysztof AdAmCZYK i Jerzy BrusiŁO, „Znaczenie bydła domowego w symbolice i wierzeniach człowieka", w Zwierzęta gospodarskie w mitach $i$ wierzeniach, red. Jarosław Chyb (Kraków: Wydawnictwo Uniwersytetu Rolniczego 2019), 26.

${ }^{6}$ Oślica ratuje Balaama (Lb 22, 22-35), kruki karmią Eliasza (1 Krl 17, 6), wieloryb wybawia Jonasza (Jon 2).

${ }^{7}$ Znana zasada „nie zawiążesz pyska wołowi młócącemu zboże” pochodzi z księgi Powtórzonego Prawa $(25,4)$, która mówi też o tym, że trzeba pomóc zwierzęciu przy upadku pod wpływem ciężaru (22, 1-4), oraz zakazuje wymagać od mniejszego zwierzęcia nieproporcjonalnego wysiłku, np. zaprzęgać wołu razem z osłem $(22,10)$.
} 
W Starym Testamencie pod wpływem literatury sąsiadów Izraela pojawiło się wiele roślin i zwierząt, a autorzy biblijni zaczęli wykorzystywać zwierzęta w nauczaniu i napominaniu narodu wybranego ${ }^{8}$. W czasach Starego Przymierza rośliny i zwierzęta były jeszcze składane Bogu jako ofiary, ale już Chrystus zastąpił krwawą ofiarę ze zwierząt postaciami chleba i wina.

W chrześcijaństwie zwierzęta stanowią część świata stworzonego, za który człowiek wyraża wdzięczność Bogu, służą człowiekowi w jego potrzebach i w relacjach człowieka z Bogiem, ale nie są już ubóstwiane. W pobożności ludowej zwierzęta występują jako atrybuty świętych i błogosławionych (św. Eligiusz, św. Hieronim, św. Franciszek z Asyżu, św. Piotr Chryzolog, św. Roch z Montpellier), towarzyszą i pomagają ludziom w życiu, a ich liczebność, zdrowie i użyteczność wiążą się z pomyślnością, dostatkiem materialnym, powodzeniem życiowym i podkreślają status społeczny ludzi. Te wszystkie znaczenia wiązały się u wiernych z wdzięcznością Bogu, były dowodem Jego błogosławieństwa ludziom na ziemi i zadatkiem dóbr wiecznych.

\section{ZWIERZETA W DUSZPASTERSTWIE}

Obok znaczenia zwierząt w Piśmie Świętym, ich związku z człowiekiem z racji miejsca w hierarchii wśród stworzeń i zobowiązań ludzi wobec zwierząt (troski, opieki, odpowiedzialności za nie), Katechizm Kościoła Katolickiego mówi o zwierzętach w kontekście powinności moralnych człowieka (dział II - siódme przykazanie), jednak tematykę zwierząt pomija już w swoich dokumentach Sobór Watykański II i podstawowe opracowania teologii pastoralnej ${ }^{10}$. W Piśmie Świętym, Tradycji, w źródłach i dokumentach kościelnych, podobnie jak w teologii katolickiej nie znajdziemy podstaw dla duszpasterstwa zwierząt czy duszpasterstwa dla zwierząt, w znaczeniu „zorganizowanej działalności zbawczej Kościoła urzeczywistniającej w służbie człowieka zbawcze dzieło Chrystusa" ${ }^{11}$.

Chociaż pojęcie duszpasterstwa wiąże się z biblijnym obrazem pasterza i owiec, to zwierzęta (nie tylko owce) nie mogą stanowić celu działalności zbawczej Ko-

${ }^{8}$ Por. Anna Maria WAJdA, Szkice z biblijnego zwierzyńca (Kraków: Wydawnictwo Petrus, 2016), 12.

${ }^{9}$ „Pobożność ludowa należy do pozaliturgicznych form kultu chrześcijańskiego; jest przejawem kultu prywatnego lub wspólnotowego wynikającego z wiary chrześcijańskiej, którą wyraża się nie przez formy liturgiczne, lecz czerpie wzory oraz inspirację z ducha i kultury własnego narodu". Czesław Krakowiak, „Pobożność ludowa”, w Leksykon teologii pastoralnej, red. Ryszard Kamiński, Wiesław Przygoda i Marek Fiałkowski (Lublin: Towarzystwo Naukowe KUL), 2006, 627.

${ }^{10}$ Leksykon liturgii, red. B. Nadolski (Poznań: Pallottinum, 2006); Leksykon teologii pastoralnej.

${ }^{11}$ Ryszard Kamiński, Wiesław PrZyGODA, „Duszpasterstwo”, 201. 
ścioła, tak jak to jest w przypadku człowieka. Zwierzęta, zwłaszcza domowe, hodowlane i towarzyszące człowiekowi, gdy występują obok człowieka w jego relacji z Bogiem, relacji z innymi ludźmi czy gdy wspólnie z człowiekiem dzielą trudności życiowe, łącznie z oczekiwaniem na odkupienie całego stworzenia z niewoli zepsucia (por. Rz 8, 19-22), nie mogą być ani podmiotem, ani przedmiotem duszpasterstwa w ścisłym znaczeniu tego słowa.

Ochrona środowiska, w tym także problematyka zwierząt, nie stanowi głównego zadania Kościoła ${ }^{12}$. Zwierzęta mogą stać się przedmiotem zainteresowania Kościoła w perspektywie jego teologicznej analizy środowiska naturalnego i odpowiedzialności człowieka za nie ${ }^{13}$. Zatem z punktu widzenia teologii pastoralnej zwierzęta wraz $\mathrm{z}$ całym stworzeniem mogą być w świetle Objawienia Bożego pośrednio przedmiotem naukowej analizy teraźniejszej sytuacji Kościoła i świata (człowieka i przyrody), mającej następnie zastosowanie do formułowania zasad i dyrektyw, według których duszpasterze powinni realizować proces zbawczy w odniesieniu do ludzi ${ }^{14}$.

Człowiek jest podstawową drogą Kościoła i głównym celem działalności zbawczej Kościoła, a „stworzenie z upragnieniem oczekuje objawienia się synów Bożych [...] i aż dotąd jęczy i wzdycha w bólach rodzenia [...] w nadziei, że również i ono zostanie wyzwolone z niewoli zepsucia, by uczestniczyć w wolności i chwale dzieci Bożych" (Rz 8, 19-22). Wydaje się zatem, iż całe stworzenie, w tym także zwierzęta, mają swoje miejsce przewidziane w odwiecznych planach Bożych. Misja Kościoła jest ukierunkowana na cele nadprzyrodzone, ale jest realizowana w realiach życia ziemskiego, dlatego pośród swoich licznych zadań Kościół dostrzega również troskę o środowisko przyrodnicze. W związku z powyższym można uznać, iż zwierzęta wraz z całym stworzeniem, obok człowieka mają na swój sposób, inaczej niż ludzie, udział w dziele zbawienia. Toteż wydaje się uzasadnione błogosławieństwo zwierząt rozumiane jako udzielenie Bożej pochwały dla zwierząt, wspieranie ich w zdrowiu i służbie człowiekowi. Jak Bóg od początku świata błogosławi całe stworzenie, dlatego że jest Jego stworzeniem ${ }^{15}$, tak całe stworzenie ma także jakiś udział w Jego dziele zbawczym.

${ }^{12}$ Por. Marek FiaŁkowski, „Ekologia”, w Leksykon teologii pastoralnej, red. Ryszard Kamiński, Wiesław Przygoda, Marek Fiałkowski (Lublin: Towarzystwo Naukowe KUL, 2006), 235.

${ }^{13}$ „W działalności na rzecz ekologii Kościół wykorzystuje katechezę, konferencje, dni skupienia i rekolekcje, oddziaływanie poprzez konfesjonał, obchody liturgiczne niektórych świąt (np. Dzień Życia, wspomnienie św. Franciszka, patrona ekologów), okresowe nabożeństwa (np. błogosławieństwo pól), odczyty i wystawy, środki społecznego przekazu itp.”. FiaŁKowsKi, „Ekologia”, 237.

${ }^{14}$ Por. Kamiński i PrZygoda, „Duszpasterstwo”, 839, 846-847.

${ }^{15}$ „Bóg jest ponad wszystko błogosławiony. On, jedyny dobry, wszystko dobrze uczynił, aby swoje stworzenia napełnić błogosławieństwami [...]”. Obrzędy błogosławieństw. Dostosowane do zwyczajów diecezji polskich, t. 1 (Katowice: Księgarnia św. Jacka, 2010), 11. 


\section{BŁOGOSŁAWIEŃSTWO ZWIERZĄT}

O błogosławieństwie zwierząt ${ }^{16}$, które znajduje swoje oparcie w religijności i pobożności ludowej, jako ,uświęcenie pewnych posług w Kościele, pewnych stanów życia, najrozmaitszych okoliczności życia chrześcijańskiego, a także użytkowania rzeczy potrzebnych człowiekowi” (KKK 1668), obszerniej traktuje dwutomowy zbiór obrzędów błogosławieństwa ${ }^{17}$. Ogólnie, wobec wszystkich osób, miejsc i rzeczy, zbiór we wprowadzeniu określa znaczenie błogosławieństwa w historii zbawienia, opisuje jego rolę w życiu Kościoła oraz szczegółowo formułuje zasady sprawowania błogosławieństwa. Każde błogosławieństwo, w którym uczestniczy człowiek, uwielbia Boga za wszelkie dobro i jest wyrażone: pokropieniem wodą pobłogosławioną, nałożeniem rąk, wyciągnięciem rąk, znakiem krzyża ${ }^{18}$. Rodzi się jednak uzasadnione pytanie, czy błogosławieństwo może odnosić się do zwierząt w taki sposób jak do osoby ludzkiej?

Jak wykazano wyżej, ściśle rzecz biorąc, duszpasterstwo dotyczy przede wszystkim człowieka i nie może być w formie liturgicznej odnoszone do zwierząt, ale błogosławienie zwierząt poza liturgią, w kontekście obchodów odpustu parafialnego, uroczystości ku czci Boga za pośrednictwem świętych Pańskich (z atrybutami zwierząt) jest działaniem teologicznie poprawnym, ponieważ „błogosławieństwa odnoszą się przede wszystkim do Boga, którego wielkość i dobroć wysławiają [...] odnoszą się także do ludzi, którymi Bóg rządzi i opiekuje się w swojej opatrzności oraz zwracają się również do rzeczy stworzonych, których obfitością i różnorodnością Bóg błogosławi człowiekowi" ${ }^{19}$. Znaczenie pobłogosławionych zwierząt wśród błogosławionych rzeczy materialnych wyjaśnia encyklika Laudato si' w słowach: „Inne istoty żywe mają właściwą sobie wartość wobec Boga oraz «przez samo swoje istnienie błogosławią Go i oddają Mu chwałę» (KKK 2416, ponieważ «Pan się raduje z dzieł swoich» (por. Ps 104, 31)" i dalej - cytując biskupów niemieckich w kontekście istot żywych - mówi o „priorytecie być przed być użytecznym”, wyraźnie odróżniając istoty żywe od rzeczy nieożywionych i polecając, aby: ,[...] człowiek szanował dobroć każdego stworzenia, by unikać nieuporządkowanego wykorzystania rzeczy" (LS 69) ${ }^{20}$.

${ }^{16} \mathrm{~W}$ języku polskim niewiele jest opracowań na ten temat. Warty odnotowania jest artykuł: Tadeusz SyCZEwski, „Obrzęd błogosławieństwa zwierząt”, Studia Teologiczne - Białystok - Drohiczyn - Łomża, 14(1996), 139-145.

${ }^{17}$ Obrzędy blogosławieństw.

${ }^{18}$ Słowo „błogosławieństwo” z łac. „,benedictio” („,bene” - dobrze, „dicere” - mówić) znaczy: dobrze mówić (o kimś), mówić dobre słowa, chwalić, chwalić dziękować względem osób, rzeczy, wydarzeń. Por. Leksykon liturgii, 169-70.

${ }^{19}$ Obrzędy blogostawieństw, 12-13.

${ }^{20}$ FranciszeK, Encyklika ,L Laudato si'”. W trosce o wspólny dom (Kraków: Wyd. M, 2015), nr 69. 
Przykładem współczesnej praktyki błogosławienia zwierząt, spełniającej warunki teologiczne w duszpasterstwie parafialnym, jest odpust św. Rocha z Montpellier, patrona liczącej 650 lat miejscowości Mikstat ${ }^{21} \mathrm{w}$ południowej Wielkopolsce, położonej między Ostrzeszowem a Ostrowem Wielkopolskim ${ }^{22}$. Kult św. Rocha rozpoczął się w Mikstacie na przełomie XVI i XVII wieku i rozwinął wraz z fundacją (1786 r.) do dziś istniejącego drewnianego kościoła św. Rocha na Wzgórzu Cmentarnym na przedmieściach Mikstatu jako wotum dziękczynnego za uratowanie za wstawiennictwem św. Rocha miasta od „morowego powietrza” ${ }^{23}$. Z tamtych czasów pochodzi stosowany do dziś zwyczaj błogosławienia zwierząt (błędnie nazywany przez niektórych wiernych, „poświęceniem zwierząt”), odbywający się każdego roku 16 sierpnia, w święto patrona miasta i w dzień odpustu św. Rocha. Błogosławieństwo zwierząt św. Rocha, którego życie było związane ze słynnym psem, wyżłem towarzyszącym Świętemu, nie jest w centrum uroczystości odpustowej (chociaż niektórzy bardziej jako turyści niż jako pielgrzymi przyjeżdżają tylko na widowiskowy przemarsz zwierząt ze swymi opiekunami i na ich błogosławienie) i stanowi tylko jeden z punktów dwudniowych uroczystości religijnych. Najpierw, już od 15 sierpnia, w uroczystość Wniebowzięcia NMP, odbywa się procesja eucharystyczna ulicami miasta (z kościoła parafialnego do kościoła św. Rocha), całonocna adoracja Najświętszego Sakramentu z Mszą Świętą o północy i dopiero następnego dnia rano, po Mszy Świętej wotywnej św. Rocha, odbywa się obrzęd błogosławieństwa zwierząt ${ }^{24}$.

W trakcie samego błogosławieństwa często obecny w Mikstacie na uroczystościach biskup ordynariusz (obecnie ks. biskup Edward Janiak, parafia należy do diecezji kaliskiej) lub miejscowy proboszcz (obecnie posługuje tam ks. kanonik Krzysztof Ordziniak, kustosz diecezjalnego sanktuarium św. Rocha) kropi wodą święconą przechodzących ludzi i zwierzęta, odmawiając formułę błogosławieństwa ${ }^{25}$ z przesłaniem, aby zwierzęta, które Stwórca dał człowiekowi, służyły mu, zaspokajając jego potrzeby w drodze do życia wiecznego, za wstawiennictwem św. Rocha.

${ }^{21}$ Św. Roch jest także patronem podróżujących, więźniów, chorych na choroby zakaźne zwierząt i ludzi oraz patronem polskich lekarzy weterynarii.

${ }^{22}$ Ludność 1952 mieszkańców (dane z 2015 r.), siedziba gminy miejsko-wiejska, parafia św. Trójcy; por. Jerzy Aleksander SplitT, Mikstat. Opowieść o mieście białej lilii i św. Rocha. Dzieje miasta do 1945 roku (Mikstat: Miasto i Gmina Mikstat, 2016), 7.

${ }^{23}$ Por. SplitT, Mikstat, 276.

24 „Początkowo na ten obrzęd przyprowadzano wyłącznie zwierzęta, które pomagały ludziom w pracy, bądź stanowiły podstawowe źródło utrzymania, ale od lat osiemdziesiątych XX wieku na święceniu pojawiają się także dzieci i dorośli z hodowanymi przez siebie małymi zwierzętami”. SplitT, Mikstat, s. 281-282.

${ }^{25}$ Przykładowy tekst, por. Obrzędy błogosławieństw, 316. 
Odnośnie do samego kultu świętych - co jest widoczne w Mikstacie - Kościół przypomina, że „ostatecznym celem kultu świętych jest uwielbienie Boga i uświęcenie człowieka przez życie w pełni zgodne z wolą Bożą i przez naśladowanie cnót

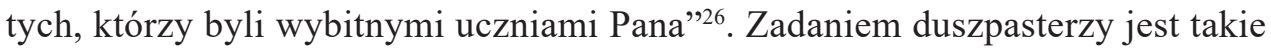
przedstawienie osoby świętego, aby nie przeakcentować wydarzeń legendarnych czy mocy cudotwórczych w jego życiu, ale ukazywać znaczenie ,jego osobowości chrześcijańskiej, głębi jego świętości i skuteczności ewangelicznego świadectwa, osobistego charyzmatu, którym ubogacił on życie Kościoła"27.

\section{ZASADY DUSZPASTERSKIE BŁOGOSŁAWIEŃSTWA ZWIERZĄT}

Wprowadzenie teologiczno-pastoralne do błogosławieństwa zwierząt podkreśla, że „zgodnie z planem opatrzności Boga Stwórcy wiele zwierząt w pewien sposób uczestniczy w życiu ludzi: służą im pomocą w pracy, dostarczają pożywienia, a niekiedy nawet przynoszą pewną pociechę. Nic nie stoi na przeszkodzie, aby w pewnych okolicznościach, np. w dniu jakiegoś świętego, zachowany był zwyczaj upraszania dla zwierząt Bożego błogosławieństwa"28. Zwierzęta nie są w tym obrzędzie celem samym w sobie, ale „,...] jak w każdym innym, zawiera [się w błogosławieństwie] uwielbienie Boga za obdarowanie świata w Jezusie Chrystusie i jednocześnie zawiera prośbę o Jego pomoc w codziennym życiu. To uwielbienie Stwórcy jest wyrazem wiary i ufności, która przyjmuje cały świat - a więc także i zwierzęta - jako stworzony przez Niego i odnosi cały istniejący wszechświat do Stwórcy jako źródła ostatecznego celu"29. W przypadku duszpasterskiego charakteru błogosławieństwa zwierząt konieczne jest również zachowanie konkretnych warunków błogosławieństwa zwierząt. „Obrzęd może być sprawowany przez kapłana lub diakona, albo przez osobę świecką, z zastosowaniem jednak czynności i formuł dla niej przewidzianych” (nr 722). „Zachowując zawsze strukturę i podstawowe elementy obrzędu, można wybrać z niego pewne części w celu dostosowania go do miejscowych okoliczności” (nr 723).

\footnotetext{
${ }^{26}$ Por. Kongregacja ds. Kultu BożEgo i Dyscypliny Sakramentów, Dyrektorium o pobożności ludowej i liturgii. Zasady i wskazania (Poznań: Pallottinum, 2003), 151.

${ }^{27}$ Kongregacja, Dyrektorium, 163-4.

${ }^{28}$ Obrzędy błogostawieństw, 310.

${ }^{29}$ SycZewsKi, Obrzęd blogostawieństwa, 141.
} 
Błogosławieństwo ma wtedy sens i może się odbyć w formie dłuższej lub skróconej, gdy zaznaczony jest właściwy kontekst obrzędu i będzie zawierał niezbędne elementy $^{30}$. Po pozdrowieniu zebranych na błogosławieństwie szafarz rozpoczyna znakiem krzyża i wprowadza do przyjęcia błogosławieństwa opisem znaczenia zwierząt w życiu i powołaniu człowieka, pomocą mu w zrozumieniu dziejów zbawienia (z podaniem przykładów z Pisma Świętego) i udziałem zwierząt w odkupieniu całego stworzenia przez Chrystusa. Wprowadzenie do błogosławieństwa może też zaznaczyć związek ze wspomnieniem dnia osób świętych, w którym dokonuje się obrzędu, i uwzględnić podziękowanie za szczególne miejsce i godność w stworzeniu, jakie zajmuje człowiek żyjący według Bożego Prawa. W dalszej części błogosławieństwa powinno być odczytane słowo Boże (np. Rdz 1, 1. 20-29; Rdz 2, 19-20a; Rdz 6, 17-23; Iz 11, 6-10), z odśpiewaniem psalmu i prośbami w intencji ludzi i zwierząt ze względu na ich opiekunów. Po odmówieniu próśb następuje modlitwa błogosławieństwa ${ }^{31}$, pokropienie wodą święconą i zakończenie obrzędu skierowane do ludzi, opiekunów zwierząt czy wszystkich zebranych: „Bóg, który dla dobra ludzi stworzył zwierzęta na ziemi, niech nas strzeże swoim błogosławieństwem i zawsze zachowuje w ojcowskiej opiece"32.

Trzeba jeszcze raz podkreślić, że przedmiotem błogosławieństwa nie jest samo zwierzę, ale człowiek, który opiekuje się zwierzęciem, korzysta z jego pomocy, pracy i pożywienia pochodzenia zwierzęcego, może realizować swoje powołanie, uświęcać się i żyć wiecznie z Bogiem. Pobłogosławione zwierzę jest środkiem do osiągnięcia celu nadprzyrodzonego przez człowieka i w tym błogosławieństwo od Boga pomaga zwierzęciu. Podobnie jak pomagają człowiekowi pobłogosławione rzeczy (przedmioty i sprzęty kultu, np. obrazy i dewocjonalia), okoliczności (jubileusze, dziękczynienia), miejsca (pola, domy) i inne istoty żywe (drzewa i owoce, zioła, kwiaty, pola z ich życiem, zasiewy) ${ }^{33}$. Jeśli błogosławieństwo zwierząt i przyrody, wszystkich istot żywych stanowi wyraz pobożności ludowej, to jego

\footnotetext{
${ }^{30}$ Por. Syczewski, Obrzęd błogosławieństwa, 310-317.

${ }^{31}$ „Boże, Ty w swojej mądrości wszystko stworzyłeś. Ty ukształtowałeś człowieka na swoje podobieństwo i obdarzyłeś go błogosławieństwem, aby panował nad zwierzętami. Wyciągnij swoją prawicę i spraw: niech te zwierzęta służą nam w codziennych potrzebach, abyśmy wspierani Twoją pomocą w obecnym życiu, z tym większą ufnością dążyli do życia wiecznego. Przez Chrystusa, Pana naszego". SyczewsKi, Obrzęd błogosławieństwa, 316. Warto dodać, że sformułowanie „panował nad zwierzętami” pochodzi z Księgi Rodzaju i wbrew popularnym rozumieniem nie oznacza zbijania, zadawania bólu i złemu wykorzystywaniu zwierząt, ale - według sensu biblijnego - troskę, opiekę, odpowiedzialne i z szacunkiem traktowanie zwierząt.

${ }^{32}$ Syczewski, Obrzęd błogostawieństwa, 317.

${ }^{33}$ Por. Syczewski, Obrzęd błogosławieństwa, 319.
} 
celem jest zawsze „uwielbienie Boga i prowadzenie ludzi do zbawienia [...]”34 i nie powinny wiązać się z miejscowym folklorem, zabawą, okazją do zarobku czy odpustową rozrywką.

Błogosławieństwa w duszpasterstwie (w tym również błogosławieństwa zwierząt) mogą służyć jako swoisty impuls do rozwoju procesu zbawienia, który osiąga swoje apogeum w dialogu miłości między Bogiem a człowiekiem, co zyskuje znaczące wsparcie przez głoszenie słowa Bożego, liturgię i braterskie życie chrześcijan. Szczególnie ,[...] sakramenty są uprzywilejowanym sposobem, w jaki natura jest przyjęta przez Boga i przemieniona w pośrednictwo życia nadprzyrodzonego. Poprzez kult jesteśmy zachęceni do objęcia świata na innym poziomie, [...] a błogosławiąca ręka jest narzędziem miłości Boga i odzwierciedleniem bliskości Jezusa Chrystusa, który przyszedł, aby nam towarzyszyć na drodze życia" ${ }^{35}$. Dlatego - czy to w nabożeństwach związanych z pobożnością ludową, czy w szeroko pojętym duszpasterstwie ekologicznym - błogosławienie zwierząt nie może być celem samym w sobie. Słowo Boże, sakramenty święte, zwłaszcza Eucharystia, powinny być podstawowym warunkiem sprawowania jakiegokolwiek obrzędu błogosławieństwa.

Współczesne podejście do zwierząt zmienia się z powodów kulturowych i społecznych. Tendencja do nadawania praw zwierzętom - dowartościowania ich w relacjach z człowiekiem, silniejszy związek emocjonalny człowieka ze zwierzęciem, to w pewien sposób czynniki ich uczłowieczające, niekiedy nawet przy odwołaniu się do racji teologicznych ${ }^{36}$. Słusznie trzeba poprawić nasz stosunek do zwierząt, zrezygnować z wykorzystywania ich na skalę przemysłową, zatrzymać ich wyginięcie wskutek działań człowieka, zapewnić większą opiekę i dobrostan, ale jeśli to wszystko powoduje, że dochodzi do wyniesienia praw i potrzeb zwierząt na równi z człowiekiem czy nawet ponad człowieka i znów - jak w epoce przedchrześcijańskiej - gloryfikuje się i ubóstwia zwierzęta, to czy wówczas w praktyce polepsza się ich życie? Czy uczłowieczenie zwierząt w postaci zapewnienia im np. takich samych zabiegów kosmetycznych, rozrywek, luksusowych warunków życia, łącznie $\mathrm{z}$ chęcią zaspokajania ich domniemanych potrzeb religijnych ${ }^{37}, \mathrm{z}$ błogosławień-

\footnotetext{
${ }^{34}$ Rytuał domowy. Rok rodziny katolickiej (Włocławek: Wydawnictwo Duszpasterstwa Rolników, 2010), 15.

${ }^{35}$ FranCISZEK, Encyklika „Laudato si”,', nr 235.

${ }^{36}$ Por. Andrew Linzey, Teologia zwierząt (Kraków: Wydawnictwo WAM, 2010).

${ }^{37}$ Por. Marcin BoJARSKI, „Bóg małp, gęsi i słoni”, https://www.naukaireligia.pl/bog-malp-gesi-i-sloni-25338 [dostęp: 11.03.2020].
} 
stwem w innym sensie, niż to występuje w duszpasterstwie katolickim, nie wpłynie na wiarę, praktyki religijne i życie moralne ludzi? Wzrost zainteresowania zwierzętami i nadawanie im przesadzonego znaczenia sprawia, że takie aspekty życia zwierząt, jak istnienie u nich duszy ${ }^{38}$, życie po śmierci i zbawienie stają się na gruncie teologii, a następnie w duszpasterstwie sporym problemem i wyzwaniem chrześcijan. Już pojawiają się „msze dla zwierząt”, pogrzeby i cmentarze zwierząt, a animalpastor - założyciel Animal Spirit Church - jest gotów na chrzest psa czy kota... ${ }^{39}$. Co jeszcze jest w stanie wymyśleć człowiek z „miłości” do swego ulubionego czworonożnego przyjaciela?

\section{BIBLIOGRAFIA}

AdAMCZYK, Krzysztof i Jerzy BrusiŁO. „Znaczenie bydła domowego w symbolice i wierzeniach człowieka". W Zwierzęta gospodarskie w mitach $i$ wierzeniach, red. Jarosław Chyb, 23-60. Kraków: Wydawnictwo Uniwersytetu Rolniczego, 2019.

BoJARSKI, Marcin. Bóg matp, gęsi i stoni, https://www.naukaireligia.pl/bog-malp-gesi-i-sloni25338

FIAŁKOWSKI, Marek. „Ekologia”. W Leksykon teologii pastoralnej, red. Ryszard Kamiński, Wiesław Przygoda i Marek Fiałkowski, 235-7. Lublin: Towarzystwo Naukowe KUL, 2006.

FrancisZeK. Encyklika „Laudato si ’”. W trosce o wspólny dom. Kraków: Wyd. M, 2015.

JAESCHKe, Tomasz, La lacrima di Dio, czyli 77 pytań do Animalpastora. Kraków: Wydawca Aleksandra Worek-Skupień Centralne Biuro Projektowe [b.r.w.].

KAMIŃSKI, Ryszard i Wiesław PrzYGODA, „Duszpasterstwo”. W Leksykon teologii pastoralnej, red. Ryszard Kamiński, Wiesław Przygoda i Marek Fiałkowski, 201-9. Lublin: Towarzystwo Naukowe KUL, 2006.

Kongregacja Ds. Kultu Bożego i Dyscypliny Sakramentów. Dyrektorium o pobożności ludowej i liturgii. Zasady i wskazania. Poznań: Pallottinum, 2003.

KowalCZYK, Dariusz. „Czy zwierzęta mają duszę nieśmiertelną?”. Życie Weterynaryjne 12(77) (2002): 645-8.

Krakowiak, Czesław. „Pobożność ludowa”. W Leksykon teologii pastoralnej, red. Ryszard Kamiński, Wiesław Przygoda i Marek Fiałkowski, 627-30. Lublin: Towarzystwo Naukowe KUL, 2006.

Lasota-MoskalewsKa, Alicja. Zwierzęta udomowione w dziejach ludzkości. Warszawa: Wydawnictwo Uniwersytetu Warszawskiego, 2005.

LinZeY, Andrew. Teologia zwierząt. Kraków: Wydawnictwo WAM, 2010.

Leksykon liturgii, red. Bogusław Nadolski, Poznań. Pallottinum, 2006.

Obrzędy błogosławieństw. Dostosowane do zwyczajów diecezji polskich, t. 1-2. Katowice: Księgarnia św. Jacka, 2010.

Rytuat domowy. Rok rodziny katolickiej. Włocławek: Wydawnictwo Duszpasterstwa Rolników, 2010. SPLitT, Jerzy Aleksander. Mikstat. Opowieść o mieście białej lilii i św. Rocha. Dzieje miasta do 1945 roku, Mikstat: Miasto i Gmina Mikstat, 2016.

\footnotetext{
${ }^{38}$ Por. Dariusz KowalczyK, „Czy zwierzęta mają duszę nieśmiertelną?”, Życie Weterynaryjne 12(77) (2002), 645-8.

${ }^{39}$ Por. Tomasz JAESChKe, La lacrima di Dio, czyli 77 pytań do Animalpastora (Kraków: Wydawca Aleksandra Worek-Skupień Centralne Biuro Projektowe [b.r.w.]), 23-5.
} 
Syczewski, Tadeusz. „Obrzęd błogosławieństwa zwierząt”. Studia Teologiczne Białystok - Drohiczyn - Łomża 14(1996), 139-45.

Szyjewski, Andrzej. Etnologia religii. Kraków: Zakład Wydawniczy Nomos, 2001.

Śledzianowski, Jan. Dehumanizacja człowieka i humanizacja zwierząt. Kielce: Jedność, 2014.

WAJDA, Anna Maria. Szkice z biblijnego zwierzyńca. Kraków: Wydawnictwo Petrus, 2016.

\section{DUSZPASTERSTWO WOBEC BŁOGOSŁAWIEŃSTWA ZWIERZĄT}

\section{Streszczenie}

Zwierzęta od dawna towarzysząc człowiekowi, spełniały różne funkcje: od towarzyszenia i opieki przez pożywienie i źródło surowców aż do funkcji religijnych. W chrześcijaństwie zwierzęta były i są częścią świata stworzonego, za który człowiek wyraża wdzięczność Stwórcy. Występują także jako atrybuty świętych, nie są jednak już ubóstwiane. Tak jak cały świat stworzony ożywiony i nieożywiony, zwierzęta mogą być błogosławione, aby lepiej służyć człowiekowi w drodze do życia wiecznego. Interesującym przykładem obrzędu błogosławieństwa zwierząt przywołanym w artykule jest uroczysty odpust św. Rocha z Montpellier w miejscowości Mikstat. Zwierzęta są tam błogosławione, ale nie stanowi to centrum uroczystości, w której chodzi przede wszystkim o celebrowanie Słowa Bożego, sprawowanie sakramentów, co służy uwielbieniu Boga i prowadzi ludzi do zbawienia. Współcześnie często dochodzi do wyniesienia potrzeb i praw zwierząt na równi z człowiekiem, czego wyrazem są próby organizowania pogrzebów, Mszy św. i innych sakramentów dla zwierząt. Rodzi to niewątpliwie poważne wyzwania dla teologii i duszpasterstwa.

Słowa kluczowe: zwierzęta; błogosławieństwo; duszpasterstwo; człowiek; Stwórca; św. Roch z Montpellier; Mikstat. 